\title{
Causes of Persistent Otorrhea after Mastoidectomy
}

\author{
Waseem Ahmad Shah ${ }^{1}$, Sadat Rashid Khan ${ }^{2}$
}

\begin{abstract}
Otitis media is one of the most common disease entities present since prehistoric times. Its dangers \& complications have been recognized and described by Hippocrates as cited in Cawthorne "acute pain of the ear, with continued strong fever, is to be dreaded, for there is danger that the man may become delirious anddie." Since then there has been a quest to understand the underlying pathology and clinical course of the disease so that optimum treatment guidelines can be decided regarding the management of patients. Aims \& Objectives The aim of the present study is to observe the factors responsible for this persistent ear discharge after mastoidectomy so that we can give guidelines for the future so as to avoid this problem. Materials and methods: In the present study, the patients were selected from those presenting in the department of SKIMS Medical College, Dept. of ENT \& Head \& neck Surgery for follow up after Mastoidectomy, during the period of AUG 2015 to AUG 2017. The 100 cases were examined, out of which 40 cases with persistent otorrhea were selected for the study. Observations: Observations were made in relation to age, sex incidence, economic status, aural discharge, type of procedure done \& findings at Otomicroscopic examination. Conclusion: In conclusion, persistantOtorrhea after mastoid surgery was more common due to infected aircells, inadequate surgical procedure. We emphasize the importance of an adequate mastoidectomy in achieving good results when managing cholesteatoma.
\end{abstract}

Keywords: Mastoidectomy,Otorrhea.

\section{Introduction}

Otitis media is one of the most common disease entities present since prehistoric times. Its dangers \& complications have been recognized and described by Hippocrates as cited in Cawthorne" acute pain of the ear, with continued strong fever, is to be dreaded, for there is danger that the man may become delirious and die." Since then there has been a quest to understand the underlying pathology and clinical course of the disease so that optimum treatment guidelines can be decided regarding the management of patients.

Chronic Otitis Media ${ }^{2}$ implies a permanent abnormality of the pars tensa or pars flaccida, most likely a result of earlier acute Otitis Media, negative Middle Ear pressure or Otitis Media with Effusion.

Now the new classification ${ }^{3}$ of COM is as follows -

1) Healed

2) Inactive Mucosal

3) Inactive Squamous

4) Active Mucosal

5) Active Squamous

1) Healed: Also known as Tympanosclerosis or healed perforation. On otoscopy, there is thinning and/or local or general opacification of the pars tensa without perforation or retraction.

2) Inactive Mucosal: Permanent perforation of the pars tensa but the middle ear mucosa is not inflamed.

3) Inactive Squamous: Retraction of the pars flaccida or pars tensa (usually postero-superior) which has the potential to become active with retained debris.

4) Active Mucosal: Permanent defect of the pars tensa with an inflamed middle ear mucosa which produces mucopus that may discharge.

5) Active Squamous: Retraction of the pars flaccida or tensa that has retained squamous epithelial debris and is associated with inflammation \& the production of pus, often from adjacent mucosa.

6) This classification is more clinically based on an individual ear's finding and has made redundant the previous, mainly anatomical classification between 'tubotympanic' and 'atticoantral' disease. The terms safe and unsafe are also incorrect and misleading as complications can arise from any ear with active COM irrespective of its pathology.

\section{Aims \& Objectives}

The aim of the present study is to observe the factors responsible for this persistent ear discharge after mastoidectomy so that we can give guidelines for the future so as to avoid this problem

\section{Materials and Methods}

In the present study, the patients were selected from those presenting in the SKIMS Medical College, Dept. of ENT \& Head \& neck Surgery for follow up after Mastoidectomy, during the period of AUG 2015 to AUG 2017. The 100 cases were examined, out of which 40 cases with persistent otorrhoea were selected for the study.

Inclusion criteria

Patients who underwent Mastoidectomy( Corticalmastoidectomy, Canal wall up and Canal wall down mastoidectomy)

\section{Exclusion criteria}

Patients with Tympanoplasty procedure.

\section{Observations}

In the present study, the patients were selected from those presenting in the SKIMS Medical College, Dept. of ENT \& Head \& neck Surgery for follow up after Mastoidectomy, during the period of AUG 2015to AUG 2017. The 100 cases were examined, out of which 40 cases with persistent otorrhoea were selected for the study.

A period of 24 months was taken into study. 


\section{International Journal of Science and Research (IJSR) \\ ISSN (Online): 2319-7064}

Index Copernicus Value (2016): 79.57 | Impact Factor (2015): 6.391

Table 1: Showing the incidence of Post-Mastoidectomy Otorrhoea.

Total number of cases -100

\begin{tabular}{|c|c|c|}
\hline $\begin{array}{c}\text { Post-operative cases } \\
\text { (with or without otorrhoea) }\end{array}$ & No. of cases & Percentage \\
\hline Cases with dry ears & 60 & $60 \%$ \\
\hline Cases with discharging ears & 40 & $40 \%$ \\
\hline
\end{tabular}

Out of 100 post mastoidectomy cases reported to ENT Department, 60 cases $(60 \%)$ had dry ears and 40 cases (40\%) had still discharging ears.

Table 2: Showing the age incidence (out of 40 cases)

\begin{tabular}{|c|c|c|}
\hline Age Group (in years) & No. of cases & Percentage \\
\hline $0-10$ & 6 & 15 \\
\hline $11-20$ & 11 & 27.5 \\
\hline $21-30$ & 12 & 30 \\
\hline $31-40$ & 8 & 20 \\
\hline 41 and above & 3 & 7.5 \\
\hline
\end{tabular}

It was observed that the youngest case reported was that of a child of 10 years and the oldest was of 60 years of age. It would appear that the commonest age groups during which patients were attending the hospital for aural discharge after mastoidectomy falls under the age group of 21 to 30 years of age.

Table 3: Showing the sex incidence

\begin{tabular}{|c|c|c|}
\hline Sex & No. of cases & Percentage \\
\hline Males & 24 & 60 \\
\hline Females & 16 & 40 \\
\hline
\end{tabular}

The observations made on sex incidence showed that male patients predominated over their female counterparts in this series, the exact number being 24 (i.e. 60\%) made while female patients were only $16(40 \%)$ in number.

Table 4: Showing the quantity, character and smell of the aural discharge

\begin{tabular}{|l|c|c|}
\hline \multicolumn{1}{|c|}{ Discharge } & No. of cases & Percentage \\
\hline Quantity & & \\
Scanty & 27 & 67.5 \\
Moderate & 11 & 27.5 \\
Copious & 2 & 5 \\
\hline Character & & \\
Mucoid & 2 & 5 \\
Mucopurulent & 14 & 35 \\
Purulent & 24 & 60 \\
\hline Smell & & \\
Foetid & 22 & 55 \\
Non-foetid & 18 & 45 \\
\hline
\end{tabular}

It was observed that in this series, the quantity of discharge in 27 cases was scanty $(67.5 \%)$, in 11 cases $(27.5 \%)$ it was moderate and in only $2(5 \%)$ cases the discharge was copious.

Regarding character, purulent discharge was present in 24 $(60 \%)$ of cases, followed by mucopurulent discharge in 14 $(35 \%)$ cases and in least number of cases discharge was mucoid i.e. in $2(5 \%)$ cases. Regarding smell, foetid discharge was seen in $22(55 \%)$ cases and non-foetid discharge in $18(45 \%)$ of the cases.
Table 5: Showing culture report of aural swab

\begin{tabular}{|c|c|c|}
\hline Culture & No. of cases & Percentage \\
\hline Staph aureus & 8 & 20 \\
\hline Proteus & 4 & 10 \\
\hline Ps. Aeruginosa & 5 & 12.5 \\
\hline E. Coli & 3 & 7.5 \\
\hline Mixed & 7 & 17.5 \\
\hline Mycoses & 4 & 10 \\
\hline Anaerobes & 1 & 2.5 \\
\hline No growth & 8 & 20 \\
\hline
\end{tabular}

It was observed after culture \& sensitivity test of aural swab that only 32 cases showed some growth. Out of these positive cases, Staphylococcus aureas was reported to be the commonest organism isolated in 8 cases $(20 \%)$. In 7 cases $(17.5 \%)$ the growth was mixed and Pseudomonas aeruginosa was found in 5 cases $(12.5 \%)$ while Proteus in 4 cases and E. Coli in 3. Mycoses were found in 4 cases (10\%). Anaerobes were cultured only from 1 case $(2.5 \%) .8$ cases did not show any growth

Table 6: Showing type of procedure done

\begin{tabular}{|c|c|c|}
\hline Type of operation & No. of cases & Percentage \\
\hline Cortical mastoidectomy & 25 & 62.5 \\
\hline $\begin{array}{c}\text { CWD Mastoidectomy } \\
\text { (with cholesteatoma) }\end{array}$ & 5 & 12.5 \\
\hline ICW Mastoidectomy & 10 & 25 \\
\hline
\end{tabular}

Out of the 40 cases, maximum number of patients $(25)$ had undergone cortical mastoidectomy , 5 patients had canal wall down procedure and 10 patients an ICW mastoidectomy was done.

Table 7: Showing findings at microscopic examination

\begin{tabular}{|l|l|l|}
\hline \multicolumn{1}{|c|}{ Finding } & No. of cases & Percentage \\
\hline Residual disease & 27 & 67.5 \\
\hline Residual TM perforation & 32 & 80 \\
\hline Large cavity with granulations & 21 & 52.5 \\
\hline Inadequate meatoplasty & 20 & 50 \\
\hline Open ME space & 4 & 10 \\
\hline
\end{tabular}

The most common finding as such was residual TM perforation, 32 cases. The next common observation was that of residual disease in 27 patients, followed by large cavity filled with granulations in 21 and inadequate meatoplasty in 20 cases. In 4 cases, tympanic membrane grafting had not been done and the middle ear space was open.

\section{Discussion}

The present work comprises the study of the causes of persistent aural discharge after mastoid surgery.

\section{Incidence:}

In the present study on the causes of persistent discharge after Mastoidectomy, the incidence of the condition has been found to be $40 \%$ (40 of 100 cases).

Karmarkar et al in their study on 433 cases reported an incidence of persistent discharge after Mastoidectomy as $12.38 \%$ for CWD mastoidectmy and $42.4 \%$ for ICW Mastoidectomy. Vartiainen reported an incidence of $8.6 \%$ in 1993 in a cohort controlled study of 431. Zorita reported

\section{Volume 6 Issue 12, December 2017}

\section{www.ijsr.net}

Licensed Under Creative Commons Attribution CC BY 


\section{International Journal of Science and Research (IJSR) \\ ISSN (Online): 2319-7064}

Index Copernicus Value (2016): 79.57 | Impact Factor (2015): 6.391

the surgical failure rate as $17.5 \%$, Brackmann as $3 \%$, Tos as $10 \%$ and Parisier as $11 \%$.

So, our finding of incidence of post-mastoidectomy persistent otorrhoea of $13.8 \%$ is very near to that of Karmarkar et al and Vartianen.

\section{Age Incidence:}

As for as the age incidence in cases of post-mastoidectomy discharge is concerned, the commonest age group in the present study was 21 to 30 years $(30 \%)$, followed immediately by the 11 to 20 years age group (27.5\%). In the age group of 31 to 40 years it was $20 \%$ and in the age group of 0 to 10 years it was $15 \%$.

M. Sadoghi\& P. Dabirmoghaddam reported mean age of patients submitting for revision MRM as 30.1 years. Other studies also indicate more number of adult patients suffering from persistent discharge. Therefore, our finding is in accordance with these studies.

\section{Sex Incidence:}

In the present series of 40 cases, males were $24(60 \%)$ in number while females were only 16 (40\%). In a study carried out by Bercin\&Kutluhan A et al (2009) the females (22) outnumbered the males (13) while Cliff AM et al (2002) reported $62.5 \%$ incidence in males while $37.5 \%$ in females. This is perhaps because males have to lead outdoor life, hence they are more exposed to drenching in the rain, exposure to climatic variations, swimming, diving etc. Thus they are more prone to get ear, nose and throat infections.

\section{Aural Discharge:}

In the present series of 40 cases observed for persistent discharge after mastoidectomy, the aural discharge has been studied for its quantity, character and smell.

\section{Quantity:}

In the present series which was observed for the persistence of discharge after mastoid operation the quantity of discharge was scanty in $27(67.5 \%)$ cases. It was moderate in $11(27.5 \%)$ cases and copious in only $2(5 \%)$ cases.

It has been observed that the quantity of discharge in all cases of post-mastoidectomyotorrhoea was scanty where the basic pathology was thought to be in atticoantral region. Regarding quantity of aural discharge in chronic suppurative otitis media, the authors like John Ballantine and John Groves and Harold Ludman share similar views.

\section{Character and Smell:}

Regarding character it was observed in this series that discharge was mucoid in only $2(5 \%)$ cases while it was mucopurulent in $14(35 \%)$ cases and purulent in $24(60 \%)$ cases.

As for as the smell is concerned, it was foetid in $22(55 \%)$ cases, and in $18(45 \%)$ cases non-foetid. According to Shambaugh, after operation for chronic suppurative otitis media, presenting infections in mucosal cells and osteitis could cause persistence of wet mastoid cavities. In such cases discharge may be scanty and foul smelling.
It has been observed by a number of authors that purulent, foul smelling \& scanty discharge was associated with atticoantral disease. In these cases, granulations or cholesteatoma was found either in the middle ear or in the mastoid cavity. The purulent, foul smelling discharge in these cases has been attributed to the presence of cholesteatoma, bony necrosis and presence of saprophytic gram negative bacteria in such infections.

According to John Ballantine and John Groves, when infecting organisms are more virulent, or the patient is debilitated, infection may progress and discharge becomes more and more creamy yellow in colour and foul smelling.

Harold Ludman also attributed foul smelling discharge in unsafe type of chronic suppurative otitis media to bony necrosis.

This view is shared by Harold Ludman. He attributed that in chronic suppurative otitis media where the infection is coming through the Eustachian tube, the discharge is mucoid or mucopurulent, may be profuse but never foetid.

\section{Aural Swab Examination}

In all 40 cases of post mastoidectomyotorrhoea aural swab was sent for microscopic and culture examination.

\section{Gram Negative Organisms:}

The gram negative organism isolated in the present work series were B. Proteus(10\%), Ps. Aeruginosa(12.5\%) and E. $\operatorname{coli}(7.5 \%)$.

These observations are almost similar to that of Mishra et al (1990) who had isolated $10.8 \%$ of proteus species from the cases of post-mastoidectomyotorrhoea.This finding is almost similar to that of I. Friedman's figure (Ps. Aeruginosa in $12.83 \%$ and E. coli8.1\%) and only slightly more than that of Mishra et al. (1990) who isolated Ps. Aeruginosa in $9.2 \%$ cases andE. Coli from $9.2 \%$ of postmastoidectomyotorrhoea. Therefore, the findings in the present series are close to that of previous observers.

\section{Gram Positive Organisms}

In the present series of post-mastoidectomyotorrhoea, Gram positive organisms were isolated in 8 cases (20\%). Among Gram positive organisms only Staphylococcus aureus was present. Their incidence in the present series is slightly less than in the series of E. Vatriainen et al, who isolated Gram positive organisms in $22 \%$ of cases of postmastoidectomyotorrhoea.

In the present series Gram positive organisms isolated were only Staphylococci. This is similar to the series of E. Vartiainen et al. in which all gram positive organism were staphylococci.

\section{No Growth}

In the present series of 40 cases which was observed for posmastoidectomyotorrhoea, in 8 cases $(20 \%)$, no organism was isolated from aural swab culture.E. Vatriainen et al in the study of 190 cases of re-operation following failure of surgery from chronic ears found that there was no growth in 


\section{International Journal of Science and Research (IJSR) \\ ISSN (Online): 2319-7064}

Index Copernicus Value (2016): 79.57 | Impact Factor (2015): 6.391

$19 \%$ of cases. So the finding in the present series are not much more than in theirs.

In the present series, the probable explanation for negative swab could be the prolonged use of systemic antibiotics due to chronic nature of the disease.

\section{Anaerobes and Mycoses}

In the present series of 40 cases 1 case $(2.5 \%)$ had anaerobes in the post-mastoidectomyotorrhoea. Papastavros et al (1986) isolated $1.68 \%$ of anaerobes from the ear discharge from the cases of chronic suppurative otitis media. In the study of Mishra et al (1990) of the postmastoidectomyotorrhoea, mycoses were isolated in $13 \%$ of cases, which is slightly more than the observation in the present series figure $(10 \%)$.

Anaerobes and mycosis contamination were found most commonly during the early post-operative period. Perhaps, dampness of dressing due to secretions in addition to contamination during dressing are the factors responsible for it.

\section{Type of Procedure Done}

In this study, the percentage distribution of Cortical mastoidectomy, Canal Wall Down \& Intact Canal Wall procedures is $62.5 \%, 12.5 \%$ and $25 \%$ respectively.

Jose Evandro et al reported 33\% ICW and 67\% CWD mastoidectomies in their study on 200 patients while A.O. Lasisi et al gave the distribution as $16 \%, 28 \%$ and $56 \%$ for atticoantrostomy, ICW and CWD Mastoidectomy respectively. Oswaldo Cruz et al also showed more frequency of Canal wall down procedures $(66 \%)$ over Intact canal wall procedures (44\%) in their study. Therefore, our finding of predominance of canal wall down Mastoidectomy percentage being less, as our centre is a tertiary referral centre and most of the cases come late with extensive and advanced disease.

\section{Findings at Otomicroscopy}

In our study, the most common finding as such was an residual TM perforation( $80 \%$ ). The next most common observation was that of residual disease, found in $67.5 \%$. Large cavity filled with granulations were present in $52.5 \%$ of cases while an inadequate meatoplasty was present in $50 \%$ cases. In $10 \%$ cases, tympanic membrane grafting had not been done and the middle ear space was open.

In a recent study (2009) done by Bercin and Kutluhan et al, the most common causes of persistent discharge after mastoidectomy were reported to be residual disease and a narrow meatoplasty in $80.9 \%$ cases, closed supratubal recess in $71.4 \%$ and tympanic membrane perforation in $57.1 \%$ cases. Our finding of narrow meatoplasty is similar to this but the incidence of residual disease and tympanic membrane perforation is lower than this. This is probably because a canal wall down approach was used in most of the cases so better clearance of disease was achieved.

Palva $\mathrm{T}$ has quoted the main reason of failure after primary surgery to be inadequate mastoid and epitympanic bonework and failure to obliterate the medial parts of the cavity thoroughly. This is probably the reason for patients with large cavity which is by nature full of pockets and sockets to continue discharge because of lack of good epithelialization.

\section{Conclusion}

In our study, persistantOtorrhea after mastoid surgery was more common due to infected aircells, inadequate exenteration of mastoid air cells and/or inadequate meatoplasty. Bone work is generally taught well in all temporal bone workshops but no emphasis is laid on soft tissue work. We emphasize the importance of an adequate meatoplasty in achieving good results when managing cholesteatoma.

\section{References}

[1] Browning GG, Merchant SN, Kelly G et al. Chronic otitis media. In: Gleeson M, ed. Scott-Brown's Otorhinolaryngology Head and Neck Surgery. London: Hodder Arnold, 2008:3395-445

[2] Cummings Otolaryngology: Head \& Neck Surgery, 5th ed. CHAPTER 156 Otologic Symptoms and Syndrome

[3] Bluestone CD, Gates GA, Klein JO et al. Definitions, terminology and classification of otitis media. Annals of Otology, Rhinology and Laryngology.2002;111: 818.

[4] Jahn AF. Chronic otitis media: Diagnosis and treatment. Med.Clin.North. 1991,75(6):1277-91

[5] DadwalMadhuri, Mohindroo N.K.Is bacterial flora of external auditory canal responsible for CSOM. Indian Journal of Otolgyvol 16 Mar 2010 P19-22.

[6] Revision Topics in Otology By BalasubramanianThiagarajan, Dr. T. Balasubramanian page 99- 100

[7] Contribution of AmbroiseParé (1510-1590) to otology A Mudry ENT Department, University Hospital, Lausanne, Switzerland Am J Otol. 1999 Nov ;20 (6):809-13

[8] Fascia \& cartilage palisade tympanoplasty 'nine years' experience, Heermann J, Heermann H, Kopstein E, Arch otolaryngol 1970, 91:228-241

[9] GlasscockShambough Surgery of ear Aristidres A Sismams: Tympanoplasty: TM repair chapter 28 , page no 466, 467

[10] Nadol JB Jr (1985) Causes of failure of mastoidectomy for chronic otitis media. Laryngoscope 95:410-413

[11] SadeJ , Surgical planning of Treatment of Cholesteatoma and post Operative followup. Annals of Otology Rhinology Laryngology; 200 April, 109 (4): $372-6$

[12] .PalvaT.Surgical treatment of chronic middle ear disease. III. Revisions after tympanomastoid surgery.ActaOtolaryngol. 1988 Jan-Feb;105(1-2):82-9

[13] Youngs R, The histopathology of mastoidectomy cavities, with particular reference to persistent disease leading to chronic otorrhoea.Clinical Otolaryngol Allied Sci. 1992 Dec;17(6):505-10. 1.

[14] Ruhl CM, PensakML, Role of aerating mastoidectomy in noncholesteatomatous chronic otitismedia,.Laryngoscope. 1999 Dec;109(12):1924-7

\section{Volume 6 Issue 12, December 2017}



$\begin{array}{lcr}\text { [15] } & \text { Becvarovski } & \text { Atlas } \\ \text { MD.Modifiedradicalmastoidectomy: } & \text { Techniques to }\end{array}$ prevent failure.Aust J Otolaryngol. 4(1):11-5

[16] Ajalloueyan M, Experience with surgical management of cholesteatomas, Arch Otolaryngol Head Neck Surg. 2006 Sep;132(9):931-3.

[17] M. Sadoghi and P. Dabirmoghaddam, Intraoperative findings in revision mastoid surgery,ActaMedicaIranica, 45(5): 373-376; 2007

[18] Berçin S, Kutluhan A, Bozdemir K, Yalçiner G, Sari $\mathrm{N}$, Karamese O, Results of revision mastoidectomy, ActaOtolaryngol. 2009 Feb;129(2):138-41Tony Wright, Peter Valentine.

[19] O'Rahilly, Muller F. Human embryology and teratology, 3rd edn.New York: Wiley-Liss, 2001

[20] Anthony Wright; Anatomy and ultra structure of human ear ; Scott Brown's text book, volume. Basic Science; VI edition (Butterworth Heinemann); 1997; 1/1/1-1/1/50.

[21] Anson BJ, Donaldson JA. Surgical anatomy of the temporal bone, 3rd edn. WB Saunders, 1981.

[22] James O Pickles : Physiology of hearing ; Scott brown's text book of basic sciences. VI edition ( Butterworth Heinemann) 1997 ; 1/2/1-1/1/34.

[23] Paul J. Abbas Charles A. Miller.Physiology of the Auditory System.In:Otolaryngology - Head and Neck Surgery .Ed;Charles W. Cummings.3rd Ed (February 1999)2831-2874.

[24] Charles D. Bluestone, Margaret A. Kenna : Workshop on chronic suppurativeotits media, etiology and management, annals of otorhinolaryngology: supplement 1988 March /April; 98(4.1) 131(1-48).

[25] Vivian Singh, FRCS ORL-HNSa, Marcus Atlas, FRACSb , Received 3 October 2006; accepted 26 February 2007

[26] LeeK .S.,Infections of the Ear; Essential of Otolaryngolory,Head and Neck Surgery 1991;32:646659

[27] Mills K.P. Padgham N D , Management of Childhood Cholesteatoma Journal of Laryngology Otology 1991 May 105(5):343-5

[28] Sheehy JL (1978) Recurrent and residual disease in cholesteatoma surgery. ClinOtolaryngol Allied Sci 3(4):393-403

[29] Farrior JB, Farrior KA (1985) Recurrent \& residual cholesteatoma. Am J Otol 6:13-18

[30] Toner JG, Smyth GDL (1990) Surgical treatment of cholesteatoma: a comparison of three techniques. Am J Otol 11(4):247-249

[31] Veldman JE, Braunius WW (1998) Revision surgery for chronic otitis media: a learning experience. Report on 389 cases with a long-term follow-up. Ann OtolRhinolLaryngol 107:486-491

[32] Mehra YN, Dubey SP. Management of chronic discharging ear. Indian J Pediatr 1989;56:317-20.

[33] O'Leary S, Veldman E. Revision surgery for chronic otitis media: recurrent-residual disease and hearing. J Laryngol Otol. 2002; 116: 996 - 1000.

[34] Kriskovich M, Shelton C. Surgical treatment of chronic otitis media and cholesteatoma. In: Canalis RF, Lambert PR. The Ear: Comprehensive Otology. Philadelphia: Lippincott Williams and Wilkins; 2000: $447-465$.

Volume 6 Issue 12, December 2017 